\title{
Red cell survival after homograft replacement of the aortic valve
}

\author{
$M$. H. YACOU B ${ }^{1}, M$. KOTHAR I, D . K E E L I N G, \\ M. PATTERSON, A ND D. N. ROSS \\ From the National Heart Hospital and the Middlesex Hospital Medical School, London, W.I
}

\begin{abstract}
Red cell survival was studied in 21 patients following homograft replacement of the aortic valve. Autologous cells labelled with ${ }^{51} \mathrm{Cr}$ were used. The $\mathrm{T}_{2}{ }^{15} \mathrm{Cr}$ varied between 24 and 34 days, with only one patient below the normal limit of normal variations. The absence of haemolysis was confirmed by other haematological studies, including estimation of reticulocytes, serum lactic dehydrogenase, and urinary haemosiderin. Haptoglobin levels were low in most of the patients studied. In contrast to prosthetic valves there was no haemolysis in patients with regurgitation around or through the homograft valve.
\end{abstract}

Intravascular haemolysis has been described after aortic valve replacement using a mechanical prosthesis. This applies to ball valves (Marsh, 1964 ; Reed and Dunn, 1964 ; Andersen, Gabrieli, and Zizzi, 1965 ; Yacoub and Keeling, 1968) and valves constructed of flexible fabric in the form of leaflets made of different materials (Gehrmann and Loogen, 1964 ; Yacoub, Rogers, and CrosslandTaylor, 1965 ; Yeh, Ellison, and Wright, 1965 ; DeCesare, Rath, and Hufnagel, 1965 ; Rubinson, Morrow, and Gebel, 1966 ; Schade, Rowe, Young, Lockey, and Clatanoff, 1967). The degree of

1 Present address: Department of Cardiovascular Surgery, University of Chicago, 950 E 59th Street, Chicago, INinois 60637 haemolysis depends on the type of prosthetic valve and its competence (Schade et al., 1967 ; Yacoub and Keeling, 1968). Homograft aortic valves have established themselves as alternatives to mechanical prostheses (Ross, 1962; BarrettBoyes, Lowe, Cole, and Kelly, 1965 ; Hocksema, Titus, Giuliani, and Kirklin, 1966; Ross and Yacoub, 1969). One of the main advantages of aortic homograft valves is the absence of thromboembolic complications, which are one of the major hazards of prosthetic valves in spite of an adequate anticoagulant regime (Brandenburg, 1965 ; Mulder, Mazzei, and MacAlpin, 1966 ; Fraser and Waddell, 1967). This paper reports the study of haemolytic

T A B L E

HAEMATOLOGICAL INVESTIGATIONS BEFORE AND AFTER HOMOGRAFT REPLACEMENT OF THE AORTIC VALVE

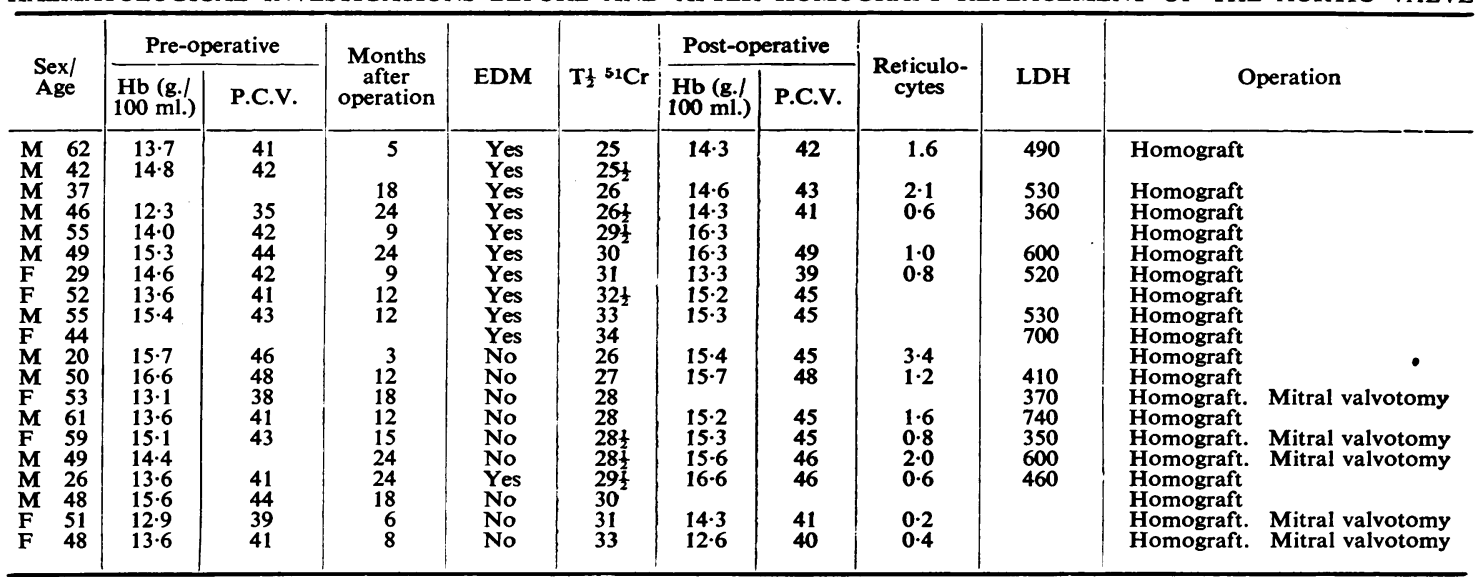


phenomena in 21 patients following the insertion of a homograft in the subcoronary area.

\section{PATIENTS AND METHODS}

The patients studied (Table) included 15 men and six women with an age range of 20 to 62 years.

Twelve patients had calcific aortic stenosis, while dominant aortic regurgitation was the main lesion in the remaining nine. Mitral valve disease requiring either valvotomy or annuloplasty in addition to aortic valve replacement was present in six patients ; 11 patients had developed early diastolic murmurs following the operation. The investigation of haemolytic phenomena was undertaken after periods ranging from four months to two years after operation.

The haematological values were determined by standard methods (Dacie and Lewis, 1963) and the ${ }^{s 1} \mathrm{Cr}$ red cell survival time by labelling autologous cells and reinjecting these into the patient under study. Serum haptoglobin levels were obtained by the colorimetric method described by Owen, Better, and Hoban (1960) in eight patients of the present series and in a further 20 in whom homograft replacement of the aortic valve was performed.

Lactic dehydrogenase was measured using routine biochemical techniques.

\section{RESULTS}

These are set out in the Table and in Figures 1 and 2. The pre-operative levels of haemoglobin, packed cell volume, and reticulocytes were all within the normal range. The post-operative levels were virtually unchanged in all patients. The lactic dehydrogenase levels were not raised postoperatively and the $\mathrm{T} \frac{1}{2}{ }^{51} \mathrm{Cr}$ varied between 24 and

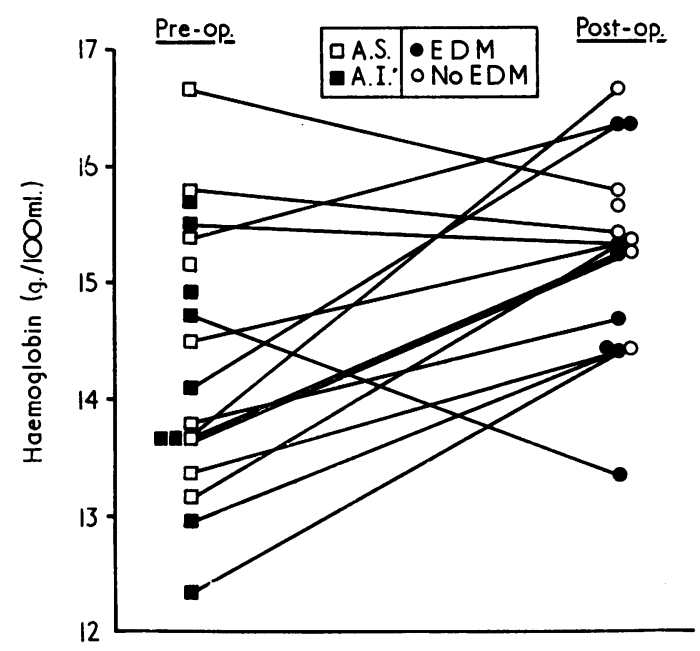

FIG. 1. Haemoglobin levels before and after homograft replacement of the aortic valve showing no significant change.

34 days, with only one patient below the lower limit of normal variation.

The haptoglobin levels were below the lower limit of normal in all but one patient, but there were no other parameters of intravascular haemolysis present; i.e., $\mathrm{T}_{\frac{1}{2}}{ }^{51} \mathrm{Cr}$ normal, no haemosiderinuria, no reticulocytosis, and a normal lactic dehydrogenase level.

\section{DISCUSSION}

Aortic valve replacement is an effective means of correcting stenosis or regurgitation. Prosthetic and

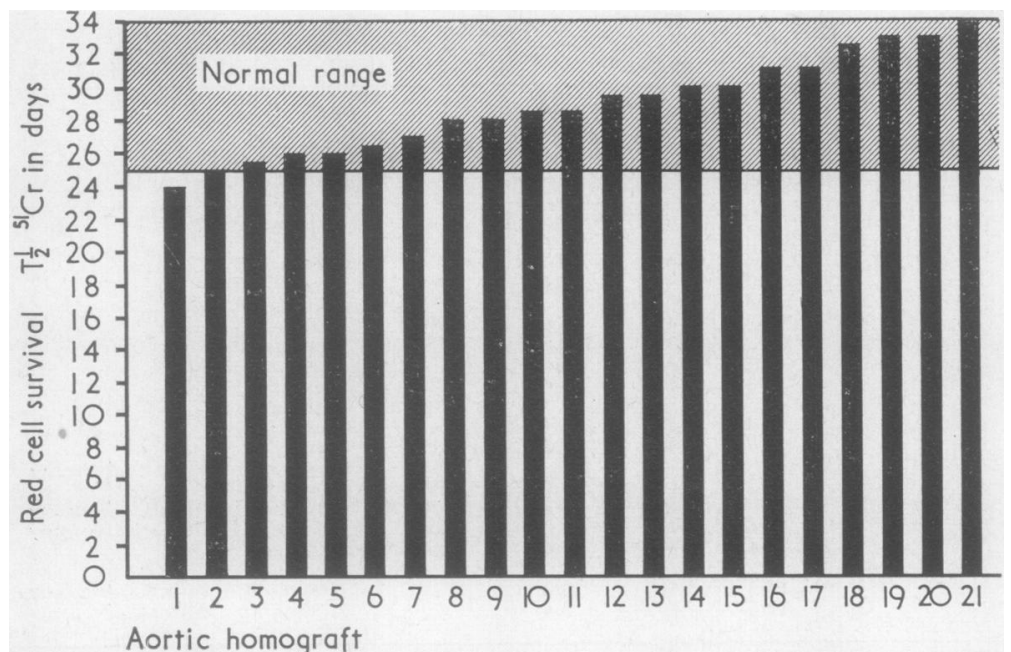

FIG. 2. Red cell survival expressed as $T \frac{1}{2}{ }^{51} \mathrm{Cr}$ in 21 patients following homograft replacement of the aortic valve. 
homograft aortic valves have been in clinical use since 1962 and mechanical disruption of the red cells is a well-recognized hazard of the use of an artificial valve. Haemolysis sufficient to cause anaemia is produced by regurgitation through or around the prosthesis and has been reported with valves made of Dacron (Gehrmann and Loogen, 1964), Teflon (Rubinson et al., 1966), and silicone rubber impregnated Teflon fabric (Schade et al., $1967)$ in addition to the ball-valve prostheses (Marsh, 1964 ; Reed and Dunn, 1964 ; Pirofsky, Sutherland, Starr, and Griswold, 1965). Leaflet valves have a high late failure rate (Braunwald and Morrow, 1965) and are now seldom used; the most widely used prosthetic valve is that originally described by Starr, Edwards, McCord, and Griswold (1963).

Previous studies (Andersen et al., 1965 ; Yacoub and Keeling, 1968) have shown that aortic ball valves will produce a chronic intravascular haemolysis even if functioning normally, but this is not severe and usually does not produce a significant anaemia. It does, however, increase the rate of clearance of the haptoglobin/haemoglobin complex from the serum and leads to deposition of haemosiderin in the liver and kidneys. The possible effects of these changes have recently been discussed (Yacoub and Keeling, 1968).

The present study shows that homograft aortic valves do not produce haemolysis even if there is

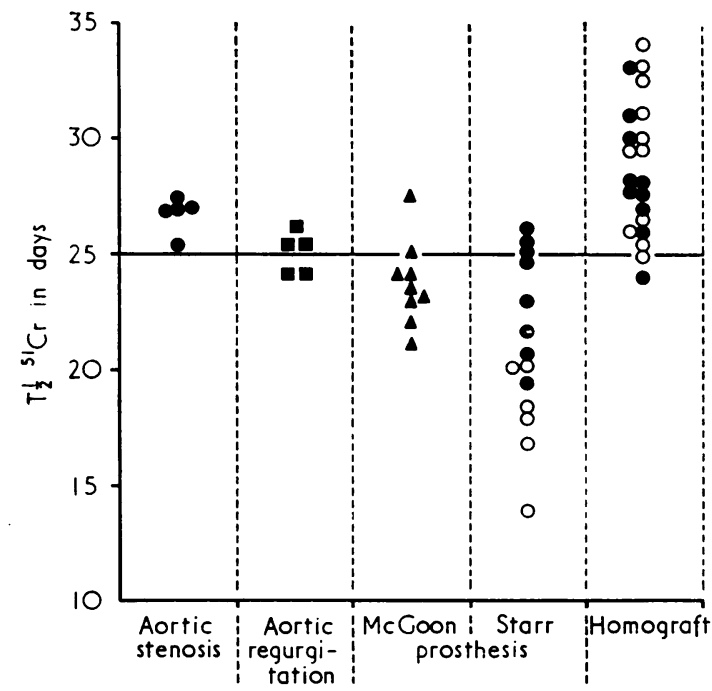

FIG. 3. Red cell survival expressed as $T^{\frac{1}{2}}{ }^{51} \mathrm{Cr}$ in patients with aortic stenosis, aortic regurgitation, and after the insertion of a McGoon prosthesis (Yacoub et al., 1965), a Starr prosthesis (Yacoub and Keeling, 1968), and a homograft (present series).

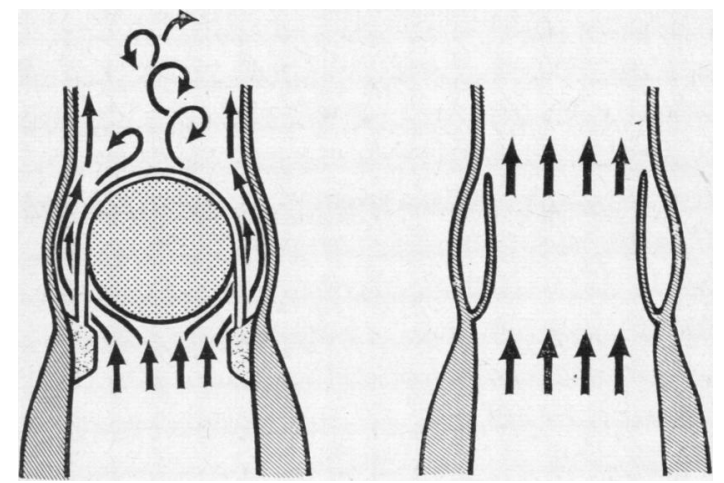

FIG. 4. Comparison between the flow characteristics of a homograft valve and a ball valve prosthesis, showing the turbulent free flow through the homograft valve.

regurgitation (Fig. 3), and this is probably due to the central flow characteristics with minimal turbulence as compared with a ball valve prosthesis (Fig. 4).

The low levels of the serum haptoglobins observed are probably due to impaired liver synthesis and an increase in the fractional catabolic rate and do not in these cases reflect the degree of haemoglobin transport or stabilization.

\section{REFERENCES}

Andersen, M. N., Gabrieli, E., and Zizzi, J. A. (1965). Chronic hemolysis in patients with ball-valve prostheses. J. thorac. Surg., 50, 501 .

Barrett-Boyes, B. G., Lowe, J. B., Cole, D. S., and Kelly, D. T. (1965). Homograft replacement for aortic valve disease. Thorax, 20, 495 .

Brandenburg, R. O. (1965). Medical problems of aortic valve replacement. Progr. cardiovasc. Dis., 7, 531.

Braunwald, N. S., and Morrow, A. G. (1965). A late evaluation of flexible Tefion prostheses utilized for total aortic valve replacement. J. thorac. Surg., 49, 485.

Dacie, J. V., and Lewis, S. M. (1963). Practical Haematology, 3rd ed. Churchill, London.

DeCesare, W., Rath, C., and Hufnagel, C. (1965). Hemolytic anemia of mechanical origin with aortic-valve prosthesis. New Engl. J. Med., 272, 1045.

Fraser, R. S., and Waddell, J. (1967). Systemic embolization after aortic valve replacement. J. thorac. Surg., $54,81$.

Gehrmann, G., and Loogen, F. (1964). Mechanical haemolytic anaemia after aortic valve replacement. Germ. med. Mth., 9, 441.

Hocksema, T. D., Titus, J. L., Giuliani, E. R., and Kirklin, J. W. (1966). Use of homografts for replacement of the aortic valve in man. Circulation, 34, Suppl. 3, p. 129.

Marsh, G. W. (1964). Intravascular haemolytic anzemia after aorticvalve replacement. Lancet, $2,986$.

Mulder, D. G., Mazzei, E. A., and MacAlpin, R. N. (1966). Ballvalve replacement for aortic valvular disease. J. thorac. Surg., 52, 76 .

Owen, J. A., Better, F. C., and Hoban, J. (1960). A simple method for the determination of serum haptoglobins. J. clin. Path., 13, 163 .

Pirofsky, B., Sutherland, D. W., Starr, A., and Griswold, H. E. (1965). Hemolytic anemia complicating aortic-valve surgery. New Engl. J. Med., 272, 235.

Reed, W. A., and Dunn, M. (1964). Fatal hemolysis following ball valve replacement of the aortic valve. J. thorac. Surg., 48, 436. 
Ross, D. N. (1962). Homograft replacement of the aortic valve. Lancet, $2,487$.

— and Yacoub, M. H. (1969). Homograft replacement of the aortic valve. A critical review. Progr. cardiovasc. Dis., 11, 275.

Rubinson, R. M., Morrow, A. G., and Gebel, P. (1966). Mechanical destruction of erythrocytes by incompetent aortic valvular prostheses. Clinical, hemodynamic and hematologic findings. Amer. Heart J., 71, 179.

Schade, S. G., Rowe, G. G., Young, W. P., Lockey, S. D., and Clatanoff, D. V. (1967). Intravascular hemolysis with the GottDaggett valve. J. thorac. cardiovasc. Surg., 53, 605.
Starr, A., Edwards, M. L., McCord, C. W., and Griswold, H. E (1963). Aortic replacement. Clinical experience with a semirigid ball-valve prosthesis. Circulation, 27, 779.

Yacoub, M. H., and Keeling, D. (1968). Chronic haemolysis following the insertion of ball valve prosthesis. Brit. Heart J., 30, 676.

_- Rogers, K., and Crossland-Taylor, P. (1965). Red cell survival in patients with aortic valve disease. Thorax, $20,367$.

Yeh, T. J., Ellison, R. G., and Wright, C. S. (1965). Hemolytic anemia due to a ruptured prosthetic aortic cusp. J. thorac. Surg., $49,963$. 